\title{
PEMBELAJARAN AKHLAK TASAWUF DAN PEMBENTUKAN KARAKTER MAHASISWA DI PERGURUAN TINGGI ISLAM
}

\author{
Sri Astuti A. Samad \\ Universitas Islam Negeri Ar-Raniry, Banda Aceh \\ Email: sriastuti@ar-raniry.ac.id
}

\begin{abstract}
Abstrak
Nilai-nilai tasawuf seperti; sabar, syukur, qana'ah dan zuhud merupakan formula sekaligus obat hati dalam mengarungi hidup dan kehidupan manusia yang semakin global. Karena itu, dengan pembelajaran akhlak tasawuf yang dipelajari oleh mahasiswa, maka diharapkan akan memberikan dampak secara psikologis dan sosial dalam kehidupannya tidak hanya di kampus sebagai lingkungan akademis tetapi juga masyarakat luas. Dengan demikian mahasiswa tersebut akan mampu memberikan kontribusi secara progresif karena nilai-nilai akhlak tasawuf telah membentuk karakter yang baik. Pada konteks ini juga perguruan tinggi keislaman akan mampu menjadi agen perubahan dalam masyarakat tidak hanya pada konteks pendidikan dan pembelajaran, tetapi juga nilai-nilai karakter yang bersumber dari dimensi keislaman yaitu tasawuf.

Kata kunci: Pembelajaran Akhlak tasawuf, Karakter, Mahasiswa, Perguruan Tinggi Islam
\end{abstract}

\begin{abstract}
Sufism values such as; patience, gratitude, qana'ah and zuhud are formulas as well as a cure for the heart in wading life and increasingly global human life. Therefore, with the learning of Sufism learned by students, it is expected to have a psychological and social impact on his life not only on campus as an academic environment but also the wider community. Thus the student will be able to contribute progressively because the values of Sufism have formed a good character. In this context also Islamic higher education will be able to become agents of change in society not only in the context of education and learning, but also character values that originate from the Islamic dimension, namely Sufism
\end{abstract}

Keywords: Learning of Sufism, Character Building, Students, Islamic Higher Education 


\section{A. PENDAHULUAN}

Saat ini Indonesia terjerumus pada krisis karakter dan akhlak, hal ini dapat dilihat pada tiga aspek; pertama, krisis integritas yang memunculkan prilaku korupsi; kedua, lemahnya etos kerja, kreativitas dan daya saing nasional; ketiga, hilangnya solidaritas sosial dan kesopanan (Zubaedi, 2017: 47). Sejalan dengan itu krisis karakter ini juga menjalar ke mahasiswa, misalnya seorang mahasiswa (RS) tega membunuh dosennya (NL) pada perguruan tinggi di Medan Sumatera Utara meninggal dunia terjadi pada 2016 (news.detik.com, Senin 02/05/2016). Kemudian pada 2017 seorang mahasiswa di Jakarta tertangkap polisi karena terlibat kasus narkoba yang berinisial ABS ditemukan 105 gram sabu dan 40 butir pil ekstasi (news.detik.com, Senin 21/08/2017). Kasus-kasus ini merupakan puncak gunung es yang jika didalami akan ditemukan lebih banyak kasus lainnya misalnya, pergaulan bebas, tawuran dan berbagai bentuk tindak kriminal lainnya. Namun dua kasus ini mengindikasikan bahwa perlu dilakukan pembentukan karakter Islami pada mahasiswa dalam proses pembelajaran.

Krisis karakter yang tersebut berdampak pada dunia pendidikan yang nyaris melupakan tujuan utamanya, yaitu mengembangkan pengetahuan, sikap, dan keterampilan secara simultan dan seimbang. Dunia pendidikan kita telah memberikan porsi yang sangat besar untuk pengetahuan (kognitif), tetapi melupakan pengembangan sikap, nilai dan perilaku (afektif) dalam pembelajarannya (Nugroho, 2017; 357). Pada posisi inilah pendidikan karakter yang menekankan aspek sikap dan perilaku akan memberikan pengaruh pada mahasiswa melalui pembelajaran Akhlak Tasawuf.

Karakter bermakna kualitas mental atau moral, kekuatan moral, nama atau reputasi. Karakter juga berarti ciri khas yang dimiliki oleh suatu benda atau individu, ciri khas tersebut adalah asli dan mengakar pada kepribadian benda atau individu tersebut dan merupakan "mesin" pendorong bagaimana seseorang bertindak, bersikap, berkata dan merespon sesuatu (Madjid dan Andayani, 2012: 11).

Pembentukan karakter dalam konteks Islam sebenarnya tidak lain adalah pendidikan akhlak yang menjadi inti pokok dari nilai keberagamaan seseorang, karena tidak sempurna agama dan iman seorang Muslim jika akhlaknya tidak baik. Azyumardi Azra (2002: 173) menjelaskan bahwa langkah untuk untuk mewujudkan pendidikan karakter yaitu menyambung kembali hubungan dan educational networks yang nyaris terputus antara ketiga lingkungan; keluarga, sekolah dan masyarakat. Pembentukan dan pendidikan karakter tidak akan berhasil selama ketiga lingkungan pendidikan tidak ada kesinambungan dan harmonisasi.

Perguruan Tinggi sebagai salah satu lingkungan pendidikan tersebut merupakan wadah pembentukan karakter mahasiswa jelas dapat dilakukan dengan memberikan pembelajaran Akhlak Tasawuf sebagai mata kuliah. Oleh karena itu, tidak berlebihan ketika Undang-Undang sistem pendidikan nasional ditegaskan tentang pentingnya pembentukan karakter yaitu pendidikan nasional berfungsi mengembangkan kemampuan dan membentuk watak serta peradaban bangsa yang bermartabat dalam rangka mencerdaskan kehidupan bangsa, bertujuan untuk berkembangnya potensi peserta didik agar menjadi manusia yang beriman dan bertakwa kepada Tuhan Yang Maha Esa, berakhlak mulia, sehat, berilmu, cakap, kreatif, mandiri, dan menjadi warga negara yang demokratis serta bertanggung jawab (UU Sisdiknas, 2003).

Muhammad Athiyah al-Abrasyi (1990: 15) menegaskan bahwa pembentukan akhlak merupakan tujuan pendidikan Islam. Artinya pendidikan yang tidak dapat berpengaruh pada 
perbaikan akhlak maka proses pembelajaran tersebut dinilai gagal. Sebab akhlak bukan hanya fitrah yang merupakan bawaan manusia sejak lahir tetapi juga dapat diperbaiki melalui pendidikan dan pembinaan.

Sejalan dengan itu, Ahmad Amin (t.th: 1) menegaskan bahwa tujuan mempelajari Akhlak dan permasalahannya menyebabkan seseorang dapat menetapkan sebagian perbuatan lainnya sebagai yang baik dan sebagain perbuatan lainnya adalah buruk. Bersikap adil adalah baik, sebaliknya berbuat zalim adalah buruk, membayar utang termasuk baik, dan mengingkari utang adalah buruk. Menurut Abuddin Nata (2012: 13) ilmu akhlak berfungsi memberikan panduan kepada manusia agar mampu menilai dan menentukan suatu perbuatan untuk selanjutnya menetapkan bahwa perbuatan tersebut termasuk kategori baik atau buruk.

Itulah sebabnya Naqiub Al-Attas memandang bahwa yang lebih tepat dengan konsep pendidikan Islam adalah al-ta'dib, bukan tarbiyah atau ta'lim. Sebab ta'dib mengandung unsurunsur ilmu (ilmu), instruksi (ta'lim) dan pembinaan yang baik (tarbiyah) (Wan Daud, 2002: 175). Pada konteks tersebut istilah $t a$ 'dib juga sangat dekat dengan adab atau peradaban yang dapat diartikan beretika dan berakhlak atau berkarakter. Problema manusia hari ini adalah krisis adab atau hilangnya nilai-nilai etika dan akhlak dalam hidupnya. Hal ini juga diakui oleh ilmuan Barat misalnya Alexis Carrel (1987) dan Fritjof Capra (2004) yang berpandangan bahwa peradaban modern telah merusak manusia secara fisik, sosial dan psikologis. Karena itu manusia perlu dikembalikan pada hakikat fitrahnya salah satunya melalui pendidikan yang mendekatkan dirinya pada akhlak Islami.

Kajian tentang pendidikan akhlak atau pembentukan karakter di Perguruan Tinggi belum banyak dilakukan tetapi beberapa penulis telah misalnya Nugraha, (2015) yang mendorong konsep bahwa sudah sewajarnya semua mata pelajaran atau mata kuliah yang diajarkan di PTKIN kepada peserta didik yang dalam hal ini adalah mahasiswa, haruslah mengandung muatan pendidikan akhlak mulia. Kemudian Nugroho, (2017) yang lebih memilih pendekatan humanis-religius dalam strategi pelaksanaanya pembelajaran pendidikan karakter dilakukan melalui penekanan tata tertib perkuliahan dan sosialisasi. Membangun hubungan harmonis, humanis dan religius, kekeluargaan, mengedepankan rasa kasih sayang, pembiasaan positif, membangun mindset positif mahasiswa, pembelajaran bermakna, dosen sebagai the living model, dan integrasi nilai-nilai ajaran Islam.

Lebih spesifik lagi temuan Shofiah dan Raudatussalamah, (2014: 219-222) pada mahasiswa UIN Suska Riau Mata kuliah Akhlak Tasawuf terbukti meningkatkan self-efficacy (kepercayaan diri) dan self-regulation (kemampuan untuk mengontrol emosi) pada mahasiswa setelah mengikuti pembelajaran Akhlak Tasawuf. Karena Mata Kuliah Akhlak Tasawuf sebagai salah satu komponen mata kuliah pada perguruan tinggi keislaman yang mengkaji dimensi akhlak manusia dari aspek norma baik dan buruk untuk diorientasikan dalam kehidupan seharihari, baik dalam kontek individual maupun sosial diharapkan mampu memberikan kontribusi pada perbaikan karakter. Tasawuf adalah ajaran untuk mengenal dan mendekatkan diri kepada Allah Swt. sehingga memperoleh kesadaran ketuhanan (God Consciousness). Oleh karena itu, tasawuf erat sekali hubungannya dengan akhlak. Akhlak yang baik timbul dari kebersihan hati, kesucian ruh, kestabilan pribadi, kemurnian sifat dan watak, karena kekuatan hati telah dialiri oleh arus kekuatan Ilahiyah. Materi yang diberikan pada mata kuliah Akhlak Tasawuf di antaranya klasifikasi Akhlak yaitu al-Akhlaq al-Mahmudah dan al-Khlaq al-Mazmumah, baik 
dan buruk dalam terminologi akhlak, kebebasan dan hati nurani sebagai tanggungjawab pembentukan akhlak, akhlak dan problem kebahagiaan.

Selain itu, di IAIN Salatiga mahasiswa belajar Akhlak Tasawuf akan memiliki kesadaran moral (moral awareness), yaitu kesediaan mahasiswa untuk menerima secara cerdas sesuatu yang seharusnya dilakukan, memiliki pengetahuan tentang nilai-nilai moral (knowing moral values), yaitu mencakup pemahaman mengenai macam-macam nilai moral seperti menghormati hak hidup, kebebasan, tanggung jawab, kejujuran, keadilan, tenggang rasa, kesopanan dan kedisiplinan. Pembelajaran akhlak tasawuf memberikan kontribusi terhadap kemampuan mengatasi masalah atau daya juang dalam mencapai keberhasilan (adversity quotient). Hal ini dibuktikan dengan pembentukan sikap dan perilaku optimis, percaya diri, mampu berbesar hati, mampu menahan cela, bercita-cita besar, menerima kritik dan mampu mencapai target (Munawaroh, 2017).

Dari latar belakang tersebut di atas maka penelitian tentang pembentukan karakter mahasiswa melalui pembelajaran Akhlak Tasawuf di perguruan tinggi menjadi penting. Karena materi-materi mata kuliah Akhlak Tasawuf memuat konsep-konsep dan sifat-sifat baik yang dapat dipraktikkan dalam kehidupan sehari-hari. Mahasiswa yang telah belajar Akhlak Tasawuf akan terstimulasi secara psikologis dan tersentuh jiwanya untuk melakukan dan mengimplementasikan sifat-sifat itu dalam kehidupan nyata. Bahkan lebih jauh sifat ini dapat ditularkan kepada orang lain dan masyarakat yang lebih luas.

\section{B. HASIL DAN PEMBAHASAN}

\section{Pembentukan Karakter Melalui Lembaga Pendidikan}

Kajian tentang pembentukan karakter pada lembaga pendidikan melalui proses pembelajaran telah dilakukan oleh peneliti sebelumnya. Beberapa kajian dapat disebutkan yaitu Asmaun Sahlan, (2015) menulis; Pendidikan Karakter dalam Perspektif Islam (Kajian Penerapan Pendidikan Karakter di Lembaga Pendidikan Islam). Ia menjelaskan bahwa penerapan pendidikan karakter di lembaga pendidikan Islam sangat diperlukan, mengingat bangsa Indonesia sekarang ini khususnya yang terjadi pada kalangan muda, yakni terjadi dekadensi moral, seperti melakukan tawuran antar siswa, minum-minuman alkohol, dan bahkan melakukan hebungan seks di luar nikah. Dengan penerapan pendidikan karakter inilah, diharapkan mampu membantu terhadap perkembangan karakter anak muda, khususnya yang masih duduk di bangku sekolah.

Agung Setiyawan, (2015) mengkaji; Pengintegrasian Nilai Pendidikan Karakter dalam Pembelajaran Bahasa Arab di Pusat Pengembangan Bahasa UIN Sunan Kalijaga Yogyakarta. Penelitian ini bertujuan untuk mengetahui nilai-nilai pendidikan karakter yang terintegrasi ke dalam pembelajaran bahasa Arab di Pembangunan Pusat Bahasa UIN Sunan Kalijaga Yogyakarta dan bagaimana mengintegrasikan dan masalah yang dihadapi oleh para profesor ketika mengintegrasikan nilai pendidikan karakter. Penelitian ini merupakan lapangan yang menunjukkan nilai-nilai pendidikan karakter telah terintegrasi meliputi: agama, jujur, toleransi, disiplin, kerja keras, mandiri, demokrasi, rasa ingin tahu, semangat kebangsaan, mengakui keunggulan, komunikatif, suka membaca, peduli lingkungan, dan tanggung jawab. Bagaimana dosen mengintegrasikan meliputi: menyesuaikan materi perkuliahan, masukkan nilai karakter. Adapun kesulitan dalam mengintegrasikan meliputi: kesulitan menyesuaikan nilai pendidikan 
karakter dengan material yang ada.

Puspo Nugroho, (2017) dalam artikelnya; Internalisasi Nilai-Nilai Karakter dan Kepribadian Mahasiswa Pendidikan Agama Islam Melalui Pendekatan Humanis-Religius. Hasil penelitian menunjukkan desain pendidikan karakter bersifat hidden kurikulum. Pada prosesnya terlaksana melalui kegiatan Tridarma Perguruan Tinggi. Strategi pelaksanaanya yaitu melalui penekanan tata tertib perkuliahan dan sosialisasi. Membangun hubungan harmonis, humanis dan religius, kekeluargaan, mengedepankan rasa kasih sayang, pembiasaan positif, membangun mindset positif mahasiswa, pembelajaran bermakna, dosen sebagai the living model, dan integrasi nilai-nilai ajaran Islam. Dengan mudahnya akses terhadap sumber nilai agama akan mampu memaksimalkan upaya mencetak kader-kader guru masa depan yang memiliki karakter dan kepribadian humanis dan religius.

Fatmawati, (2012) membahas: Fungsi Tasawuf terhadap Pembentukan Akhlak (Etika) Kerja: Studi pada Murid Tarekat Qadariyah Naqsyabandiyah di Kota Pontianak Kalimantan Barat. Menurut Fatmawati bahwa tahapan-tahapan pengamalan tasawuf oleh murid yang dibimbing oleh guru seperti prosesi bai'at (ikrar) dan prosesi zikir yang dilakukan secara konsisten berimplikasi pada akhlak (etika) kerja yang mempunyai dimensi spiritual dan nilainilai Islami. Akhlak (etika) kerja merujuk sifat-sifat Nabi Muhammad SAW, seperti sifat siddiq, amanah, fatanah dan tabligh yang masih relevan hingga kini. Ketika melakukan aktivitas kerja para pengikut tarekat tersebut merasa mempunyai kekuatan spiritual di dalam dirinya, yakni merasa selalu ada yang mengawasi. Mereka berhati-hati dalam bekerja dan selalu menjaga perilakunya sesuai akhlak Islami.

Darmiah (2016) yang membahas mengenai: Integrasi Nilai-Nilai Pendidikan Karakter dalam Pembelajaran IPA pada Program Studi Pendidikan Guru Madrasah Ibtidaiyah UIN ArRaniry. Kajian ini menjelaskan bahwa mahasiswa $86 \%$ telah mampu mengintegrasikan nilai-nilai Islam dalam pendidikan karakter melalui pemanfaatan instrument penilaian sikap ilmiah. Selebihnya hanya $24 \%$ mahasiswa yang "memerlukan perbaikan" dalam mengintegrasikan nilainilai Islam dalam pendidikan karakter melalui pemanfaatan instrument penilaian sikap ilmiah.

Kajian yang lebih fokus pada studi pembentukan karakter melalui pendidikan akhlak/akhlak tasawuf yaitu: Muhamad Tisna Nugraha, (2015) menulis: Revitalisasi Pendidikan Akhlak Mulia Dalam Pembentukan Karakter Mahasiswa di Perguruan Tinggi Agama Islam. Nugraha mendorong konsep bahwa sudah sewajarnya semua mata pelajaran atau mata kuliah yang diajarkan di PTKIN kepada peserta didik yang dalam hal ini adalah mahasiswa, haruslah mengandung muatan pendidikan akhlak mulia. Selain menekankan pentingnya akhlak mulia pada mahasiswa, para dosen secara bersama-sama harus berusaha untuk meningkatkan kualitas perkuliahan di perguruan tinggi tersebut. Tujuannya agar dapat memperjelas arah penanaman nilai-nilai akhlak mulia di perguruan tinggi dengan berbagai program-program yang nyata. Para dosen, karyawan, dan semua pimpinan perguruan tinggi harus menjadi model atau suri tauladan dalam pembentukan akhlak mulia ini di kampus.

Vivik Shofiah dan Raudatussalamah, (2014) dalam penelitiannya berjudul: Self-Efficacy dan Self-Regulation Sebagai Unsur Penting dalam Pendidikan Karakter: Aplikasi Pembelajaran Mata Kuliah Akhlak Tasawuf. Menurut kedua penulis bahwa pembelajaran Akhlak tasawuf dapat meningkatkan self-efficacy (kepercayaan diri) dan self-regulation (kemampuan untuk mengontrol emosi) pada mahasiswa UIN Suska Riau setelah mengikuti pembelajaran Akhlak 
Tasawuf. Self-efficacy dan self-regulation pada mahasiswa UIN Suska Riau tergolong tinggi dan sangat tinggi.

Fathimah Munawaroh, (2017) dalam tesisnya; Kontribusi Pembelajaran Akhlak Tasawuf Terhadap Adversity Quotient Mahasiswa IAIN Salatiga. Ia menyimpulkan bahwa pembelajaran akhlak tasawuf memberikan kontribusi terhadap kemampuan mengatasi masalah atau daya juang dalam mencapai keberhasilan (adversity quotient) mahasiswa IAIN Salatiga. Hal ini dibuktikan dengan pembentukan sikap dan perilaku optimis, percaya diri, mampu berbesar hati, mampu menahan cela, bercita-cita besar, menerima kritik dan mampu mencapai target.

Dari beberapa kajian kepustakaan tersebut akan menjadi bahan rujukan dan acuan dasar untuk menganalisis pembahasan ini lebih lanjut. Kajian ini juga menunjukkan bahwa diskursus pembentukan karakter mahasiswa melalui pembelajaran Akhlak Tasawuf bukan hal baru dalam studi pendidikan Islam di Indonesia. Penelitian sebelumnya banyak mengkaji pembentukan karakter pada lembaga pendidikan Islam secara umum atau pada mata kuliah seperti Bahasa Arab. Peneliti lain juga membahas pendidikan karakter pada perguruan tinggi namun memakai pendekatan penelitian kuantitatif. Oleh sebab itu, posisi penelitian ini jelas berbeda dengan penelitian sebelumnya yaitu pembentukan karakter mahasiswa melalui pembelajaran Akhlak Tasawuf dengan menggunakan pendekatan kualitatif dan teori-teori pendidikan Islam yang lebih cocok dengan ilmu akhlak sebagai rumpun ilmu-ilmu keislaman.

\section{Teori Pembentukan Karakter Pada Manusia}

Secara teoritis manusia dipengaruhi oleh faktor-faktor baik internal maupun eksternal, sehingga melahirkan aliran-aliran yaitu; 1) nativisme; 2) empirisme; dan 3 konvergensi. Pertama, aliran nativisme berpandangan bahwa yang paling berpengaruh dalam pembentukan karakter seseorang adalah faktor pembawaan dari dalam yang bentuknya dapat berupa kecenderungan, bakat dan akal. Jika seseorang telah mempunyai pembawaan kepada kebaikan, maka dengan sendirinya orang tersebut menjadi baik. Kedua, aliran empirisme mengatakan bahwa faktor yang mempengaruhi pembentukan diri seseorang adalah faktor dari luar, yaitu lingkungan sosial, termasuk pembinaan dan pendidikan yang diberikan. Jika pendidikan yang diberikan kepada seseorang baik, maka ia akan menjadi baik begitu pula sebaliknya. Ketiga, aliran konvergensi berpendapat bahwa pembentukan akhlak dipengaruhi oleh faktor internal pembawaan seseorang dan eksternal yaitu pendidikan dan pembinaan yang dibuat secara khusus, atau melalui interaksi dalam lingkungan sosial (Arifin, 2012: 167).

Menurut Abuddin Nata (2012: 169) aliran konvergensi lebih cocok dengan konsep pendidikan Islam. Sebab jika merujuk pada al-Quran dan Hadis maka akan ditemukan penjelasan bahwa yang mempengaruhi pembentukan karakter seseorang adalah faktor internal dan eksternal. Internal yaitu adanya fitrah (suci) sebagai sesuatu yang diciptakan oleh Allah dan faktor lingkungan keluarga dan masyarakat sebagaimana dijelaskan dalam hadis "Setiap anak yang lahir dalam keadaan fitrah, orang tuanya yang membuat ia menjadi Yahudi, Nasrani dan Majusi (HR. Bukhari).

Tokoh pendidikan Islam seperti al-Gazali dan Ibnu Miskawaih menegaskan bahwa akhlak seseorang dapat diubah melalui pendidikan, latihan, pembinaan, perjuangan keras dan sungguh-sungguh. Mereka menyimpulkan bahwa akhlak adalah hasil usaha (muktasabah). AlGazali (t.th. 54) mengatakan bahwa seandainya akhlak tidak dapat menerima perubahan, maka 
batallah fungsi wasiat, nasihat dan pendidikan dan tidak ada pula fungsi hadis Nabi yang mengatakan "perbaikilah akhlak kamu sekalian".

Oleh karena itu, pembentukan karakter seseorang melalui pendidikan dan pembinaan atau proses pembelajaran apalagi mata kuliah Akhlak Tasawuf pada perguruan tinggi jelas akan memberikan pengaruhi terhadap mahasiswa. Sebab mata kuliah Akhlak Tasawuf dipelajari mengenai akhlak yang baik dan buruk, keutamaan seseorang jika berakhlak baik, dan konsepkonsep akhlak yang baik serta tokoh-tokoh penggagas konsep akhlak tasawuf seperti al-Gazali, Ibnu Miskawaih dan sebagainya.

Lebih jauh dapat dikatakan bahwa dalam konteks pendidikan Islam karakter yang dapat muncul yaitu; 1) Tauhid, 2) Ikhlas, 3) Mencintai Ilmu, 4) Sabar, 5) Rajin Ibadah, 6) Zuhud, 7) Tawakkal, 8) Dermawan, 9) Amar Ma'ruf Nahi Mungkar, 10) Jujur, 11) rendah hati, 12) Cinta Kepada Sesama, 13) Disiplin dan 14) Pemaaf (Zulkapadri, 2014: 119). Lebih jauh menurut Ibnu Miskawaih dan al-Gazali bahwa karakter lebih dekat dengan akhlak, yaitu spontanitas manusia dalam bersikap atau melakukan perbuatan yang telah menyatu dalam diri manusia sehingga ketika muncul tidak perlu dipikirkan lagi (Nata, 2000: 54). Akhlak dalam pandangan al-Gazali adalah sifat yang tertanam dalam dalam jiwa yang menimbulkan macam-macam perbuatan dengan gampang dan mudah, tanpa memerlukan permikiran dan pertimbangan (al-Gazali, t.th.: 56).

Jika merujuk pada konsep nasional bahwa pendidikan karakter merupakan model pembelajaran yang telah dicanangkan oleh Kementerian Pendidikan Nasional pada tahun 2011. Sebagaimana dijelaskan dalam Buku Panduan Pendidikan Karakter terdapat nilai-nilai yang akan membentuk karakter. Yaitu ada 18 nilai: (1) Religius, (2) Jujur, (3) Toleransi, (4) Disiplin, (5) Kerja Keras, (6) Kreatif, (7) Mandiri, (8) Demokrasi, (9) Rasa ingin tahu, (10) Semangat kebangsaan, (11) Cinta tanah air, (12) Menghargai prestasi, (13) Bersahabat/komunikatif, (14) Cinta damai, (15) Gemar membaca, (16) Peduli Lingkungan, (17) Peduli sosial, (18) Tanggung jawab (Kementrian Pendidikan Nasional, 2011: 8). Menurut Ratna Megawangi (2010) bahwa pendidikan karakter dapat dilakukan mulai dari Pendidikan Anak Usia Dini sampai Sekolah Menengah Atas. Ia mengembangkan sembilan pilar pendidikan karakter yaitu; 1) Cinta Tuhan dan alam semesta beserta isinya; 2) Tanggung jawab, Kedisiplinan, dan Kemandirian; 3) Kejujuran; 4) Hormat dan Santun; 5) Kasih Sayang, Kepedulian, dan Kerjasama; 6) Percaya Diri, Kreatif, Kerja Keras, dan Pantang Menyerah; 7) Keadilan dan Kepemimpinan; 8) Baik dan Rendah Hati; 9) Toleransi, Cinta Damai, dan Persatuan. Meskipun demikian sifat ini dikembangkan pada level Perguruan Tinggi, sebab dalam konteks Islam pendidikan tidak mengenal batas dari ayunan sampai ke liang lahat.

Sejalan dengan itu, Lickona (1999: 5) mengatakan bahwa karakter mengandung tiga unsur pokok, yaitu mengetahui kebaikan (knowing the good), mencintai kebaikan (loving the good) dan melakukan kebaikan (doing the good). Dalam pendidikan karakter, kebaikan itu seringkali dirangkum dalam sederet sifat-sifat baik (mulia). Dengan demikian, pendidikan karakter adalah sebuah upaya membimbing perilaku manusia menuju nilai-nilai kehidupan. Upaya ini juga memberi jalan untuk menghargai persepsi dan nilai-nilai pribadi yang ditampilkan peserta didik, baik di rumah, sekolah maupun dilingkup masyarakat yang lebih luas. Fokus pendidikan karakter adalah pada tujuan-tujuan etika, tetapi praktiknya meliputi penguatan kecakapan-kecakapan yang penting yang mencakup perkembangan sosial peserta didik. 
Karena itu, pendidikan karakter dapat dimaknai sebagai pendidikan nilai, pendidikan budi pekerti, pendidikan moral, pendidikan watak, atau pendidikan akhlak yang tujuannya mengembangkan kemampuan peserta didik untuk memberikan keputusan baik-buruk, memelihara apa yang baik itu, dan mewujudkan kebaikan itu dalam kehidupan sehari-hari dengan sepenuh hati. Secara praktis, dalam konteks pendidikan Islam pembentukan karakter merupakan suatu sistem penanaman nilai-nilai kebaikan kepada peserta didik yang meliputi komponen pengetahuan, kesadaran atau kemauan, dan tindakan untuk melaksanakan nilai-nilai, baik dalam hubungannya dengan Allah, sesama manusia, dan lingkungannya sehingga menjadi manusia paripurna (Zuchdi, 2010: 2-3).

Dari penjelasan tersebut di atas maka dapat dipahami bahwa terjadi krisis karakter termasuk pada mahasiswa yang ada pada lembaga pendidikan. Karena itu pembentukan karakter mahasiswa dapat dilakukan dengan metode pembinaan dan pendidikan melalui proses pembelajaran akhlak tasawuf karena dalam mata kuliah tersebut dipelajari konsep-konsep akhlak yang baik. Sehingga pada gilirannya mahasiswa akan mengetahui dan mampu mengaplikasikan akhlak-akhlak tersebut seperti; Tauhid, Ikhlas, Sabar, Ridha, Zuhud, Tawakkal, Dermawan, Jujur, dan Qana'ah. Sifat-sifat semacam ini sangat penting dalam kehidupan manusia saat ini ditengah gelombang modernisasi dan globalisasi.

\section{Implementasi Nilai-Nilai Akhlak Tasawuf dan Pembentukan Karakter}

Meskipun perkembangan dunia sudah mewarnai seluruh penjuru dunia, misalnya; politik, ekonomi, hukum, budaya dan lain sebagainya. Tetapi nilai-nilai tasawuf tetap relevan dengan perkembangan zaman, karena itu peran tasawuf dalam kehidupan modern sangatlah penting. Jelasnya nilai-nilai tasawuf tetap relevan dengan perkembangan modern. Berikut ini akan dipaparkan beberapa nilai-nilai akhlak tasawuf yang dapat berpengaruh terhadap pembentukan karakter mahasiswa yaitu: qana'ah, zuhud, sabar, dan syukur.

\section{a. Sifat Qana'ah}

Qana'ah kepuasan jiwa terhadap rezki yang diberikan. Qana'ah juga dapat berarti merasa cukup dan menerima apa adanya. tentang definisi ini sudah dijelaskan sebelumnya. Seseorang yang mempunyai sifat qana'ah merasa cukup dengan harta dan nikmat yang ada ditangannya dan tidak memikirkan harta orang lain. Orang yang demikian tidak akan serakah hidupnya (alNaisabury, 1996: 174).

Barang siapa yang sudah memperoleh rizki, dan sudah ada untuk dimakan sesuap pada waktu pagi dan petang, hendaklah tenangkan hati, jangan merasa ragu dan cemas. Setiap orang tidak dilarang berkerja mencari penghasilan, tidak disuruh berpangku tangan dan malas lantaran harta sudah ada, karena yang demikian bukan qana'ah, akan tetapi hanya faktor kemalasan. Berkerjalah, karena manusia diciptakan untuk beribadah kepada Allah Swt dan bekerja, Tetapi tenangkan hati dan jiwa, yakinkanlah bahwa di dalam bekerja ada yang untung dan ada yang rugi. Dengan demikian jelaslah bahwa bekerja bukan karena memandang harta yang belum memadai, tetapi bekerja lantaran orang hidup tidak boleh bermalas-malasan, melainkan harus rajin dan kreatif dalam menjalani kehidupan.

Seiring terdengar kata-kata dari golongan orang yang salah sangka dan kurang paham rahasia agama. Mereka melemparkan satu tuduhan, bahwa agama membawa manusia malas, karena agama senantiasa mengajak umatnya membenci dunia, menerima apa yang ada, pasrah 
dengan takdir Allah. Mereka tidak berusaha melepaskan diri dari keterbelakangan, kemiskinan, kebodohan dan ketertindasan. Sebab itu maka bangsa yang malas akan terpuruk ke dalam kemiskinan dan kebodohan, sebaliknya rajin, ulet, dan tekun akan menjadi bangsa yang maju dan sejahtera.

Selain itu muncul kekeliruan pemahaman terhadap qana'ah. Mereka mengira bahwa qana'ah ialah menerima apa adanya saja, sehingga mereka tidak berusaha lagi. Mereka menaknai qana'ah adalah orang yang tenggelam dalam mihrab mesjid, selalu memakai surban yang panjang, kemudian tidak mempedulikan kehidupan dunia. Mengatur hidup yang damai, mengatur kepandaian, mencapai ilmu dunia untuk kemaslahatan agama, mereka sangka semuanya tidak boleh dan dilarang dalam agama. Padahal pandangan yang semacam itu merupakan pemahaman yang salah.

Sejatinya qana'ah, dianjurkan dalam agama adalah qana'ah hati, bukan qana'ah ikhtiar. Karena itu kisah di masa sahabat Rasulullah Saw, ada seseorang yang orang kaya, gigih berjuang, harta banyak, rumah mewah, unta tidak terkira, perdagangannya antara negara, tetapi ia seorang yang bersifat qana'ah (Hamka, 2005: 219-220).

Oleh karena itu, perlu dicatat bahwa faedah qana'ah dalam kehidupan sehari-hari sungguh besar manfaatnya, di ketika harta itu tiba-tiba terbang dan hilang atas izin Allah Swt. Seseorang yang bersifat qana'ah akan selalu tenang jiwanya, damai hatinya dan tidak risau dengan kehidupan dunia, menurutnya nikmat pemberian Allah pasti cukup untuk dia dan keluarganya. Tegasnya sifat qana'ah sangat relevan dalam masyarakat modern tak terkecuali masyarakat Aceh yang sering ditimpa cobaan.

Masyarakat Aceh sekarang ini diperhadapkan dengan serangan budaya Barat berupa materialisme, komsumerisme dan hedonisme. Terutama sesudah musibah gempa dan tsunami Aceh menjadi daerah yang tingkat perputaran uang yang sangat tinggi, banyak bantuan masuk baik dari dalam maupun dari luar negeri. Sebagian masyarakat terutama masyarakat kota menikmati kondisi tersebut, jika mereka tidak memiliki sifat qana'ah maka mereka akan menjadi manusia yang tidak puas dengan harta dan nikmat yang diberikan oleh Allah kepada mereka. Mereka akan berubah menjadi manusia yang cinta materi dan kekayaan. Disinilah letak pentingnya sifat qana'ah yaitu merasa cukup dan menerima apa adanya dari Allah.

\section{b. Sifat Zuhud}

Asy-Syibli mengatakan bahwa zuhud adalah kehendak seseorang untuk menjauhkan diri dari segala sesuatu selain Allah. Sedangkan Abu Sulaiman al-Darany mengatakan bahwa zuhud adalah menjauhkan diri dari apapun yang memalingkan seseorang dari Allah (al-Naisabury, 1996: 111-113). Pada hakikatnya orang Islam boleh dan sah-sah saja memiliki harta kekayaan yang cukup dan banyak, tetapi tidak boleh mencintai harta dengan tidak wajar, sehingga lupa mengingat dan beribadah kepada Allah Swt. Padahal harta dalam Islam mempunyai fungsi sosial, adapun fungsi harta dalam Islam antara lain: 1) Menumbuhkan solidaritas sosial; 2) Menghilangkan jurang pemisah antara orang kaya dan miskin; 3) Menghancurkan nafsu kapitalisme dan individualisme.

Islam menentang penumpukan dan akumulasi kekayaan untuk kepentingan sendiri, hal itu dilarang karena dapat menimbulkan kemiskinan dan kemungkaran, melahirkan sikap angkuh dan berfoya-foya serta pemerasan, Allah Swt memerintahkan agar umat Islam menginfakkan sebagian harta yang dimilikinya untuk kemaslahatan umat. 
Sikap zuhud dalam artian menjauhi dunia sangatlah mudah untuk realisasikan dalam kehidupan ini, karena sikap zuhud ini sangatlah dianjurkan dalam agama, dan sangat relevan dengan dunia yang modern sekalipun. Dalam membatasi diri terhadap masalah dunia, bahkan menjauhi dunia, karena dalam definisi Imam al-Ghazali menjauhi dunia ialah segala sesuatu yang tidak ada manfaatnya untuk akhirat.

Oleh sebab itu, tertepislah anggapan sebagian kalangan bahwa kalau menjauhi dunia sangatlah sulit, padahal segala liku-liku kehidupan ini dapat bermanfaat bagi akhirat. Semua ini tergantung pada niat masing-masing, dalam agama tidak dilarang mencapai kemegahan, jika kemegahan itu pergunakan pada jalan Allah.

Patut dicatat bahwa sangatlah keliru pendapat yang mengatakan bahwa sufisme terdahulu kelihatannya cenderung tertutup terhadap pemikiran di luar (Siregar, 1999: 316-317). Pandangan yang seperti ini dapat mengotori dunia tasawuf, padahal tasawuf sangat relevan dalam aspek apapun, baik sosial, ekonomi, politik, maupun budaya. Jadi pada intinya harus diingat bahwa zuhud sangat dapat direalisasikan dalam dunia modern, karena menurut para sufi bahwa derajat yang tinggi orang zuhud di dunia adalah mereka yang menepati petunjuk Allah Swt dalam mencintainya. Maka janganlah terbebani dengan sifat zuhud, dan jangan mengira bahwa zuhud akan membuat orang sengsara dan menderita karena meninggalkan aktivitas duniawi.

Perlu ditegaskan di sini zuhud bukanlah membelakangi dan tidak peduli dengan dunia, seperti sangkaan sebagian kalangan. Tetapi zuhud adalah tidak menggantungkan hati dan jiwa manusia terhadap persoalan-persoalan duniawi. Harta dan kekayaan tidak membuat lalai untuk mengingat kepada Allah. Kemudian persoalan dunia tidak dapat dilupakan, sebab dunia merupakan jembatan menuju akhirat. Sesudah beribadah dia bertebaran di muka bumi mencari rezki dari Allah.

\section{c. Sifat Sabar}

Sabar adalah bersifat teguh terhadap Allah swt dan menerima cobaan-cobaan-Nya dengan sikap lapang dada dan tengang (al-Naisabury, 1996: 210). Sabar menurut Imam alGhazali adalah jika dipandang sebagai pengekangan nafsu dan amarah daripada tuntutannya kepada perbuatan yang cenderung melangkahi nilai-nilai syari'at, dinamakan sebagai kesabaran jiwa (sabar nafsu). Sedangkan menahan terhadap penyakit fisik disebut sebagai sabar badani, maka kesabaran jiwa sangat dibutuhkan dalam berbagai aspek kehidupan, karena dengan adanya kesabaran justru mempertimbangkan segala sesuatu gerak jiwa yang emosional, oleh karena demikian, maka kesabaran sangat dibutuhkan dalam kehidupan (Anwar, 2000: 72). Dalam menghadapi dunia modern, sifat sabar yang demikian apabila terapkan, maka dalam menghadapi segala hal akan membawa dampak yang positif, sehubungan dengan itu sebuah kata mauidhah bahasa, menegaskan: "Kesabaran itu dapat membantu menyelesaikan berbagai urusan."

Maka dengan adanya pernyataan di atas dapat dikatakan bahwa diperlukan kesabaran supaya terlaksana apa yang dicita-citatan. Seperti telah diketahui bahwa sejalan dengan perjalanan waktu, dunia semakin berkembang pesat, maka dalam perkembangan itu sangatlah dituntut untuk mengimplementasikan nilai-nilai tasawuf seperti banyak disebutkan dalam ayat al-Qur'an yang mengajak dan memerintahkan kita untuk bersikap sabar, antara lain, QS. Ali Imran: 200: "Hai orang-orang yang beriman, Bersabarlah kamu dan kuatkanlah kesabaranmu dan tetaplah bersiap siaga (di perbatasan negerimu) dan bertakwalah kepada Allah, supaya kamu beruntung." 
Perlu diketahui bahwa kesabaran itu ada beberapa macam; pertama, bersikap sabar untuk menjauhi larangan Allah Swt, seperti berzina, mabuk, berjudi, dan korupsi, serta laranganlarangan lainnya yang terjadi di dunia ini; Kedua, bersikap sabar dalam menjalankan perintah Allah Swt, karena berbuat taat kepada Allah Swt adalah kewajiban bagi kita umat Islam, memeliharanya terus-menerus dengan ilmu pengetahuan, serta menjaganya dan memperbaiki. Syariat menjelaskan bahwa ada perintah mengeluarkan zakat, mengerjakan shalat, puasa, haji bagi yang mampu, kemudian berlaku jujur dan bersikap lemah-lembut membantu sesama juga perintah agama.; ketiga, sabar dalam menghadapi musibah yang diturunkan oleh Allah (Tebba, 2003: 14-15).

Maka dalam hal ini dibutuhkan kesabaran supaya segala perintah, larangan Allah Swt dapat ditaati, karena dengan sabar ini juga manusia dapat tercapainya kedamaian hati dan kebahagiaan yang didambakan. Dengan pernyataan ini jelaslah penerapan sabar dalam dunia modern menjadi modal utama tercapainya kebahagiaan yang hakiki ataupun kebahagiaan dunia dan akhirat.

\section{d. Sifat Syukur}

Syukur adalah mempergunakan segala nikmat yang diberikan Allah Swt untuk menaati segala perintah-Nya. Selaku orang mukmin yang begitu banyak menerima nikmat Allah Swt, maka sudah layak bersyukur kepada-Nya, orang mukmin diwajibkan untuk bersyukur, karena ada dua sebab yang mendasarinya: 1) Agar kekal nikmat yang sangat besar itu, karena apabila tidak disyukuri nikmat itu tidak berkat dan akan hilang dengan sendirinya; 2) Agar nikmat yang diberikan Allah Swt bertambah sesuai dengan Firman-Nya; "Sesungguhnya jika kamu bersyukur, sungguh aku akan menambah nikmat kepadamu, dan jika kamu mengingkarinya, sungguh azabKu sangat pedih (QS. Ibrahim: 7)

Seseorang yang bersyukur kepada nikmat dari Allah Swt, nikmat itu akan bertambah. Karena rasa syukur kepada Allah Swt yang telah melimpahkan segala nikmatnya kepada makhluk di dunia terus-menerus. Dengan bersyukur kenikmatan akan kekal menjadi milik orang yang bersyukur tersebut, sebaliknya apabila tidak bersyukur nikmat tersebut hilang dan berpindah tempat. Syukur merupakan salah satu perintah syara', maka dengan adanya rasa syukur berarti seseorang telah menjalankan perintah syara'. Melaksanakan perintah syara' berarti akan diridhai oleh Allah Swt, karena dalam hidup ini yang diharapkan hanyalah keridhaan Allah yang dituntut bukan yang lain.

Saat ini perubahan dunia sangat cepat, manusia diperhadapkan dengan zaman modern, manusia telah banyak yang lupa daratan, tidak lagi mempergunakan nikmat Allah Swt pada tempatnya. Malahan mereka menggunakan nikmat tersebut untuk semakin jauh dari Allah Swt, yakni pada hal-hal yang dilarang dan dimurkai oleh Allah Swt, maka di waktu itu Allah mengecam orang yang tidak bersyukur.

Keempat sifat tersebut di atas sangat urgen bagi manusia dalam menghadapi kehidupan modern. Semua ini juga dapat menjadi formula atau obat hati bagi kegundahan dan kerisauan jiwa manusia. Di samping itu sifat-sifat tersebut juga sering disebut sebagai maqamat atau stasion yang harus dilalui oleh seorang sufi. Selain maqamat juga ada istilah hal atau ahwal (keadaan) yang dialami oleh seorang sufi dalam menempuh perjalanan tasawuf. Hal tersebut misalnya; mahabbah (perasaan cinta yang mendalam pada Tuhan), khawuf (takut), musyahadah (penyaksian), ittihad (penyatuan dengan Tuhan) dan sebagainya. 
Jadi dengan demikian jika nilai-nilai tasawuf mampu dihayati, diimplementasikan dalam kehidupan manusia, maka ia akan mampu memberikan jalan keluar dari seluruh problemanya, khusus dalam mencari kebahagiaan hati dan ketentraman jiwa. Sebab tasawuf berfungsi untuk memperbaiki akhlak dan budi pekerti dan membersihkan batin manusia, dan mampu membawa kebahagiaan pada manusia (Hamka, 2005: 3).

Hanya manusia yang bersih hati dan tentram jiwanya yang akan menemukan hakikat kemanusiaan yang sebenarnya. Ketika manusia mampu mengetahui hakikat dirinya maka ia akan mengenal Allah, merasakan bahkan senantiasa dekat dengan-Nya. Pada saat itulah manusia akan memperoleh kebahagiaan hati dan keterentraman jiwa, suatu kondisi yang diidam-idamkan semua orang. Manusia inilah yang dinamakan sebagai insan kamil (manusia yang sempurna).

\section{KESIMPULAN}

Manusia modern yang mendewakan materi, akal dan ilmu pengetahuan ternyata gagal memberikan makna dan tujuan hidup. Akibatnya manusia mengalami krisis kehidupan, kehilangan visi keilahian, kendali diri dan kehampaan spiritual. Pada saat itulah nilai-nilai tasawuf menjadi begitu urgen bagi manusia, sebab jalan tasawuf terbukti mampu memberikan solusi alternatif bagi problema kehidupan manusia. Selain itu, hakikat manusia adalah mempunyai fitrah atau suci, sifat fitrah juga dapat diartikan sebagai manusia diciptakan Allah mempunyai naluri beragama yaitu agama tauhid. Jika ada manusia tidak beragama tauhid, maka hal itu tidaklah wajar dan tidak sesuai dengan fitrah manusia itu sendiri.

Dengan demikian nilai-nilai tasawuf seperti; qana'ah, zuhud, sabar, dan syukur merupakan formula sekaligus obat hati dalam mengarungi hidup dan kehidupan manusia yang semakin global. Obat tersebut akan menjaga manusia di tengah krisis zaman modern ini sehingga dia tidak mengalami kehampaan hati dan kekeringan jiwa. Meskipun sebelumnya banyak orang memberikan penafsiran yang salah terhadap tasawuf khususnya sifat zuhud sebagai menjauhi dunia, padahal yang dimaksud adalah tidak menggantungkan diri pada dunia. Harus diketahui pula bahwa dunia adalah jalan menuju akhirat (balaghun ila al-akhirat), dengan adanya pandangan bahwa dunia harus dijauhi maka pandangan tersebut harus dicermati secara seksama. Menjauhi dunia sebagaimana yang dimaksudkan Hasan al-Basri adalah tidak menggantungkan hati dan jiwa pada dunia.

Pada akhirnya masyarakat modern yang diperhadapkan dengan zaman yang tidak membawa mereka pada kebahagiaan yang hakiki, mereka hidup berkecukupan dari segi harta dan materi namun jiwa dan hati mereka kosong dan kering oleh siraman agama. Mereka kehilangan eksistensinya sebagai manusia, kesepian dan kesunyian dalam belantara globalisasi. Pada konteks inilah peran dan fungsi tasawuf sangat signifikan. Dengan demikian urgensi tasawuf tetap masih diperlukan sebagai solusi alternatif bagi kegelisahan hidup manusia. Sebab tasawuf menawarkan sejumlah formula untuk menjawab problematika kehidupan manusia terutama mendapat ketentraman jiwa dan kedamaian hati. 


\section{DAFTAR PUSTAKA}

Al-Gazali, Muhammad. (t.th.). Ihya' 'Ulum al-Din, Kairo: Dar al-Taqwa.

Al-Naisabury, Imam al-Qusyairy. (1996). Risalatul Qusyairiyah: Induk Ilmu Tasawuf, Surabaya: Risalah Gusti.

Amin, Ahmad, (t.th.). Kitab Akhlak, Mesir: Dar al-Kutub al-Misriyah.

Anwar, Rosihan. (2000). Ilmu Tasawuf, Bandung,: Pustaka Setia, 2000.

Asmani, Jamal Ma'mur. (2012). Buku Panduan Internalisasi Pendidikan Karakter di Sekolah, Yogyakarta: Diva Press.

Azra, Azyumardi. (2002). Pendidikan Islam: Tradisi dan Modernisasi Menuju Milenium Baru, Jakarta: Logos Wacana Ilmu.

(2002). Paradigma Baru Pendidikan Nasional; Rekonstruksi dan Demokratisasi, Jakarta: Kompas.

Capra, Fitjof. (2004). Titik Balik Peradaban, Yogyakarta: Bentang.

Carrel, Alexis. (1987). Man the Unknown (Misteri Manusia),Terjemahan, Bandung: Remaja Karya.

Fatmawati. (2012). "Fungsi Tasawuf terhadap Pembentukan Akhlak (Etika) Kerja: Studi pada Murid Tarekat Qadiriyah Naqsyabandiyah di Kota Pontianak Kalimantan Barat", Jurnal Teologia, Volume 25, Nomor 2, Juli-Desember.

Hamka (2005). Tasawuf Modern, Jakarta: Pustaka Panjimas.

Idris, Tasnim dan Darmiah. (2017), Integrasi Nilai-Nilai Pendidikan Karakter dalam Pembelajaran IPA pada Program Studi Pendidikan Guru Madrasah Ibtidaiyah UIN ArRaniry, Laporan Penelitian Pusat Penelitian dan Pengabdian Masyarakat UIN ArRaniry.

Jalaluddin dan Ramayulis. (1993). Pengantar Ilmu Jiwa Agama. Jakarta: Kalam Mulia.

Kementerian Pendidikan Nasional. (2011). Panduan Pelaksanaan Pendidikan Karakter, Jakarta: BALITBANG Pusat Kurikulum dan Perbukuan.

Kesuma, Dharma dkk., (2011). Pendidikan Karakter: Kajian Teori dan Praktik Sekolah, Bandung: Remaja Rosdakarya.

Kronologi Mahasiswa UMSU Medan Tusuk Dosen Hingga Tewas, news.detik.com, Senin 02 Mei 2016.

Mahasiswa Pengedar Sabu dan Ekstasi Jaringan LP Cipinang Ditangkap, news.detik.com, Senin 21 Agustus 2017.

Majid, Abdul dan Dian Andayani. (2012). Pendidikan Karakter Prespektif Islam, Bandung: Rosda Karya.

Megawangi, Ratna. (2010). Membangun Karakter Anak Melalui Brain-based Parenting (Pola Asuh Ramah Otak), Depok: Indonesia Heritage Foundation. --. (2010). Sekolah Berbahaya Bagi Perkembangan Karakter Anak: Solusi Bagaimana Mempersiapkan Sekolah Menjalankan Pendidikan Karakter, Depok: Indonesia Heritage Foundation.

Mulyasa, E. (2011). Manajemen Pendidikan Karakter, Jakarta: Bumi Aksara.

Munawaroh, Fathimah. (2017). Kontribusi Pembelajaran Akhlak Tasawuf Terhadap Adversity Quotient Mahasiswa IAIN Salatiga, Tesis IAIN Salatiga.

Nata, Abuddin, (2000). Akhlak Tasawuf, Jakarta: Grafindo Persada.

Nugraha, Muhamad Tisna, (2015). Revitalisasi Pendidikan Akhlak Mulia Dalam Pembentukan Karakter Mahasiswa di Perguruan Tinggi Agama Islam, Raheema: Jurnal Studi Gender dan Anak, Vol. 2, No. 2.

Nugroho, Puspo, (2017). Internalisasi Nilai-Nilai Karakter dan Kepribadian Mahasiswa Pendidikan Agama Islam Melalui Pendekatan Humanis-Religius, Edukasia: Jurnal Penelitian Pendidikan Islam, Vol. 12, No. 2, Agustus. 
Ryan, Kevin \& Karen E. Bohlin. (1999). Building Character in Schools: Practical Ways to Bring Moral Instruction to Life. San Fransisco: Jossey-Bass a Wiley Imprint.

Sahlan, Asmaun. (2015). Pendidikan Karakter dalam Perspektif Islam (Kajian Penerapan Pendidikan Karakter di Lembaga Pendidikan Islam, Jurnal el-Hikmah UIN Malang, Volume II.

Shofiah, Vivik dan Raudatussalamah. (2014). Self-Efficacy dan Self-Regulation Sebagai Unsur Penting dalam Pendidikan Karakterisepi(Aplikasi Pembelajaran Mata Kuliah Akhlak Tasawuf), Kutubkhanah: Jurnal Penelitian Sosial Keagamaan, Vol.17, No.2, JuliDesember.

Siregar, A. Rivay. (1999). Tasawwuf dari Sufisme Klasik Ke Neo Sufisme, Edisi Revisi, Jakarta: Raja Grafindo Persada.

Tebba, Sudirman. (2003). Tasawuf Positif, Jakarta: Kencana.

UU Republik Indonesia Nomor 20 Tahun 2003 tentang Sistem Pendidikan Nasional, Pasal (3).

Zubaedi, (2017). Strategi Taktis Pendidikan Karakter: Untuk PAUD dan Sekolah, Jakarta: Raja Grafindo.

Zuchdi, Darmiyati, dkk. (2010). Pendidikan Karakter dengan Pendekatan Komprehensif, Yogyakarta: UNY Press.

Zulkapadri, Syahrial. (2014). Pendidikan Karakter dan Pendidikan Akhlak (Studi Perbandingan) Jurnal al-Ta'dib Universitas Islam Darussalam Gontor, Vol. 9, No. 1, Juni. 